\title{
Increased dispersion of oil from a deep water seabed release by energetic mesoscale eddies
}

\author{
Ryan M. Gilchrist ${ }^{\mathrm{a}, \mathrm{b}}$, Rob A. Hall ${ }^{\mathrm{a}}$, John C. Bacon ${ }^{\mathrm{b}}$, Jon M. Rees ${ }^{\mathrm{b}}$, Jennifer A. Graham ${ }^{\mathrm{b}}$ \\ ${ }^{\mathrm{a} C e n t r e ~ f o r ~ O c e a n ~ a n d ~ A t m o s p h e r i c ~ S c i e n c e s, ~ S c h o o l ~ o f ~ E n v i r o n m e n t a l ~ S c i e n c e s, ~ U n i v e r s i t y ~ o f ~}$ \\ East Anglia, Norwich Research Park, Norwich, NR4 7TJ, UK \\ ${ }^{\mathrm{b}}$ Centre for Environment, Fisheries and Aquaculture Science, Pakefield Road, Lowestoft, Suffolk, \\ NR33 OHT, UK \\ *Corresponding author.E-mail address: robert.hall@uea.ac.uk
}

\section{Highlights:}

- An oil spill is simulated in the deep Faroe-Shetland Channel, forced by hydrodynamic models with different horizontal resolutions.

- Explicitly resolving mesoscale eddies leads to dramatically increased horizontal pollutant dispersion at and below the surface.

- A change in stratification leads to differences in subsurface plume trapping depth and subsequent far-field transport.

\begin{abstract}
Hydrodynamics play a critical role in determining the trajectory of an oil spill. Currents, stratification and mesoscale processes all contribute to how a spill behaves. Using an industryleading oil spill model, we compare forecasts of oil dispersion when forced with two different hydrodynamic models of the North-West European Shelf $(7 \mathrm{~km}$ and $1.5 \mathrm{~km}$ horizontal resolution). This demonstrates how the trajectory of a deep water $(>1000 \mathrm{~m})$ release in the central FaroeShetland Channel is influenced by explicitly resolving mesoscale processes. The finer resolution hydrodynamic model dramatically enhances the horizontal dispersion of oil and transports pollutant further afield. This is a consequence of higher mesoscale variability. Stratification influences the depth of subsurface plume trapping and subsequently the far-field transport of oil. These results demonstrate that the choice of hydrodynamic model resolution is crucial when designing particle tracking or tracer release experiments.
\end{abstract}

Keywords: Deep water oil spills; Oil dispersion; Mesoscale eddies; Model resolution; FaroeShetland Channel; North Atlantic

Funding: RMG was funded by the UK Natural Environment Research Council (NERC) industrial CASE studentship grant NE/M010023/1, awarded to the University of East Anglia and Cefas.

\section{Introduction}

Oil spills from seabed releases are a worldwide risk to the marine environment, and drilling is gradually pushing into deeper waters as a result of resource discovery and technological innovation (Burgherr, 2007; Gallego et al., 2018). Deepwater Horizon is the highest profile example of a deep 
seabed release, costing BP $\$ 145$ billion (Lee et al., 2018) and spilling 7-8 $\times 10^{5} \mathrm{~m}^{3}$ of oil over 86 days (Camilli et al., 2010; Crone and Tolstoy, 2010; McNutt et al., 2012; Joye et al., 2016). Deep water drilling also occurs in the Faroe-Shetland Channel (FSC; Fig. 1a) in the North Atlantic, which has been a region of UK oil and gas development since the early 1990s (Smallwood and Kirk, 2005). As of August 2018, there were 162 active well heads in the FSC (source: UK Oil and Gas Authority), three-quarters of which were deeper than $200 \mathrm{~m}$. A spill in the FSC lasting for a typical response time of 30 days could result in an oil release of up to $3.4 \times 10^{5} \mathrm{~m}^{3}$ (Gallego et al., 2018).

The FSC is a hydrodynamically complex and energetic environment. A strong slope current (up to $1 \mathrm{~m} / \mathrm{s}$ ) along the West Shetland slope transports warm, saline surface water north-eastwards towards the Norwegian Sea and eventually into the Arctic Ocean. Near the seabed at $>1000 \mathrm{~m}$ depth, a bottom current transports relatively cold, fresh deep water south-westwards, which either follows bathymetry through the Faroe Bank Channel into the open North Atlantic, or overflows the Wyville Thomson Ridge into the Rockall Trough (Turrell et al., 1999; Sherwin et al., 2008). Mesoscale eddies can extend across the width of the FSC and south of the Faroe Islands near the Faroe Bank Channel (Sherwin et al., 1999, 2006; Darelius et al., 2011). Large internal tides and non-linear internal waves have been observed in the region, which can act to increase turbulent mixing rates (Sherwin, 1991; Hosegood and van Haren, 2004; Hall et al., 2011, 2019). A unique stratification structure is also present, where the main thermocline typically resides at several hundred meters below the sea surface and separates the exchanging water masses (Berx et al., 2013; Fig. 1c, d, e).

The behavior of oil from a seabed release depends on ocean currents and stratification, in addition to properties of the oil such as viscosity, temperature, gas-oil ratio (GOR), flow rate and orifice diameter (Yapa and Chen, 2004). A previous plume modelling study suggested that oil will be trapped at $650-800 \mathrm{~m}$ depth from a $1000 \mathrm{~m}$ release in the FSC, depending on the release rate and ambient ocean conditions (Johansen, 2000b). Main et al. (2017) used a global ocean circulation model based on the Nucleus of European Modelling of the Oceans (NEMO; Madec, 2016) to predict the transport of oil from the FSC, and found that far-field oil transport was dependent on its depth. Oil near the surface travelled north-eastwards towards the Arctic Circle, whereas oil trapped at depth reached as far west as Greenland. However, they did not consider the influence plume dynamics might have on the vertical distribution of pollutant, or the role of surface weathering processes such as evaporation and emulsification. Additionally, the horizontal resolution of the model $\left(1 / 12^{\circ}\right)$ was coarser than required to explicitly resolve mesoscale eddies in the FSC region ( $2 \mathrm{~km}$ or less; Oey, 1998).

Oil Spill Contingency and Response (OSCAR) is a state-of-the-art modelling system that can be used to predict the fate and trajectory of an oil release during emergency response. OSCAR comprises of a 3-D fates model (Reed et al., 1995, 2000), near-field plume model (Johansen, 2000a) and droplet breakup model (Johansen et al., 2013). It is typically forced with horizontal current velocities from an operational hydrodynamic ocean model. OSCAR has been wellvalidated against historical emulsion observations (Abascal et al., 2010), synthetic aperture radar (SAR) satellite observations (Pan et al., 2020), and against the DeepSpill field experiment (Johansen et al., 2003). 

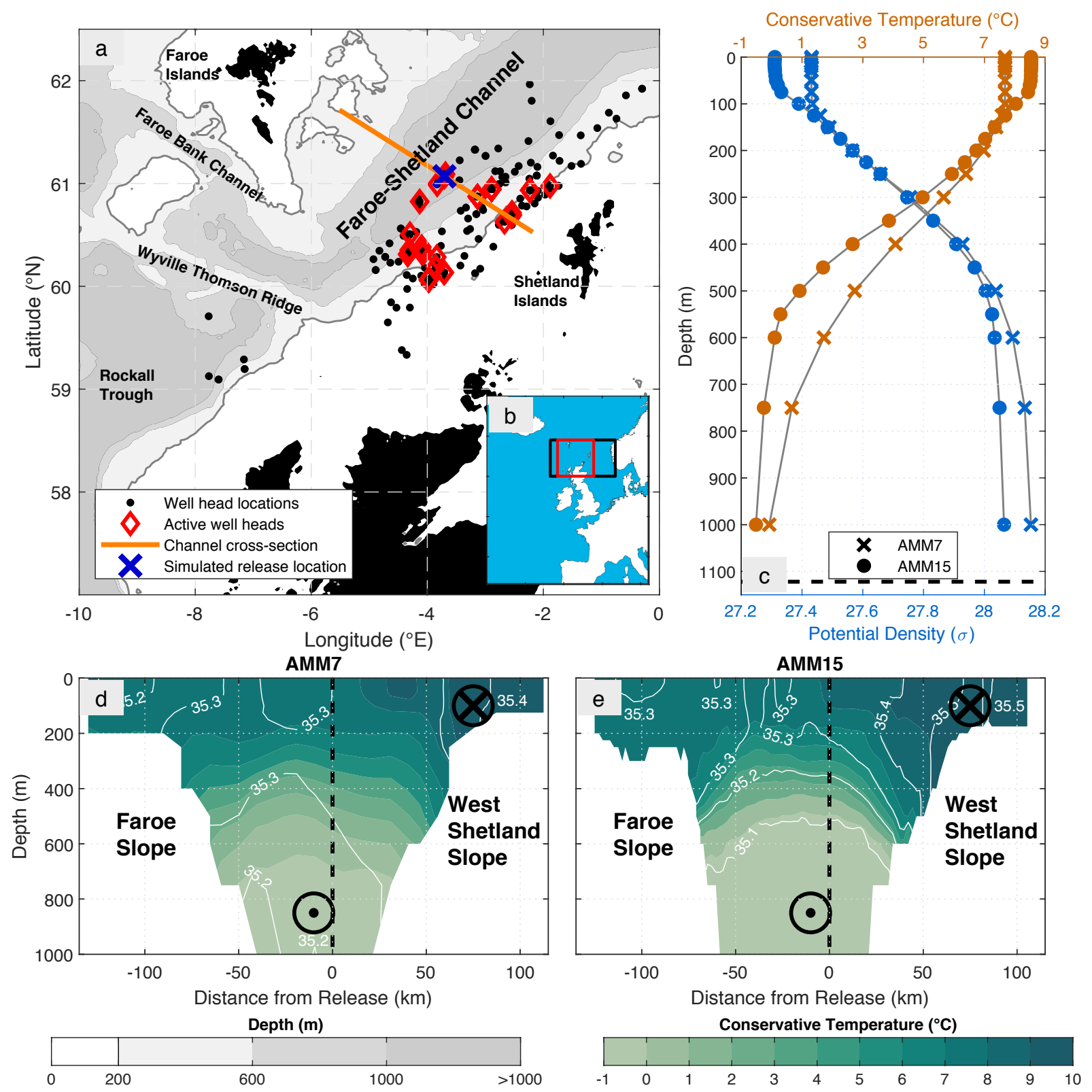

Fig. 1. Overview of the Faroe-Shetland Channel (FSC). (a) Well head locations in the FSC (source: UK Oil and Gas Authority), with active well heads shown as red diamonds, and the simulated release location shown as a blue cross. Bathymetry is from Smith and Sandwell (1997). (b) Location of the FSC as shown in (a) (red box) and the spill model domain (black box). (c) Profiles of potential density (blue) and conservative temperature (red) at the release location from both hydrodynamic models. Release depth is indicated by the dashed black line. (d, e) Representative across-channel sections of conservative temperature (filled contours, ${ }^{\circ} \mathrm{C}$ ) and absolute salinity (white contours, g/kg) from AMM7 (left) and AMM15 (right), along the orange line in (a). Release location is indicated by the dashed black line. Also shown are approximate locations and directions of the slope current and bottom current.

In this study, OSCAR is used to consider how oil from a seabed release in the FSC could be transported by hydrodynamic processes, and how an increase in hydrodynamic model resolution influences the predicted dispersion. To simplify our diagnostics, biodegradation and direct wind 
forcing are not included. We demonstrate that enhanced mesoscale variability in fine-resolution hydrodynamic models leads to a dramatic increase in horizontal dispersion, and that stratification influences the depth of trapping and subsequent far-field transport. These results will help guide the choice of hydrodynamic forcing for emergency spill forecasting.

\section{Hydrodynamic forcing}

To force OSCAR, both Oil Spill Response (OSRL) and the UK Centre for Environment, Fisheries and Aquaculture Science (Cefas) currently use operational ocean forecasts based on the UK Met Office $7 \mathrm{~km}$ horizontal resolution Atlantic Margin Model of the North-West European Shelf (FOAM AMM7 NWS, hereafter referred to as AMM7; O'Dea et al., 2012, 2017) In November 2018, an updated version of this model became available to use operationally (FOAM AMM15 NWS, hereafter referred to as AMM15; Graham et al., 2018; Tonani et al., 2019). Both models are based on NEMO v3.6. They are forced using surface pressure and wind fields, and assimilated with sea surface temperature, sea surface height and temperature/salinity profiles using the methods described by King et al. (2018). Operational output is available from EU Copernicus Marine Services Information (2018a, 2018b). This paper provides a comparison of these two hydrodynamic models when they are used to force an oil spill simulation.

AMM15 has a finer horizontal resolution of $1.5 \mathrm{~km}$, which is high enough to explicitly resolve mesoscale eddies within the FSC. Resolving bathymetry at $1.5 \mathrm{~km}$ also provides a mechanism for increased internal wave generation (Guihou et al., 2017). AMM7 and AMM15 are both run with 51 vertical levels, but the operational output of AMM15 is finer (33 vertical levels from 0-5000 m, compared with 24 for AMM7). Tonani et al. (2019) show that AMM15 performs better than AMM7 against ocean glider observations of density, and against HF radar observations of surface current velocity.

A 30-day period (1 February 2017 to 3 March 2017) is analysed, as operational outputs are available from both hydrodynamic models. Three-dimensional, hourly horizontal current velocities are used to force both the 3-D fates model and plume model. Due to limitations in the plume model, only time-constant, single-point profiles of temperature and salinity can be used to represent stratification. These are taken from the nearest hydrodynamic model grid-point to the release location on 1 February 2017 (Fig. 1c).

Figure 2 shows a surface current decomposition for both hydrodynamic models. Semidiurnal $\left(M_{2}\right)$ tidal ellipses are computed by harmonic analysis over 30 days using Utide (Codiga, 2011). Thirty-five tidal constituents are resolved using a minimum Rayleigh criterion of 1 . Residual surface currents associated with the mesoscale eddy field are extracted by de-tiding, de-meaning and de-trending the hourly currents. Surface eddy kinetic energy (EKE) per unit mass is calculated

$\mathrm{EKE}=\frac{1}{2}\left(u^{2}+v^{2}\right)$, where $u$ and $v$ are the zonal and meridional components of the residual surface currents. EKE is calculated to quantify the mesoscale current variability of both hydrodynamic models and averaged over the 30-day period. Our calculations of monthly mean EKE for AMM15 (Fig. 2h) show that the locations of enhanced eddy activity are similar to drifter observations (Sherwin et al., 2006; 0.015-0.025 $\mathrm{m}^{2} / \mathrm{s}^{2}$ within the central FSC and the Faroe Bank Channel). Mean EKE in these locations for AMM7 is considerably lower $\left(<0.005 \mathrm{~m}^{2} / \mathrm{s}^{2}\right)$. 

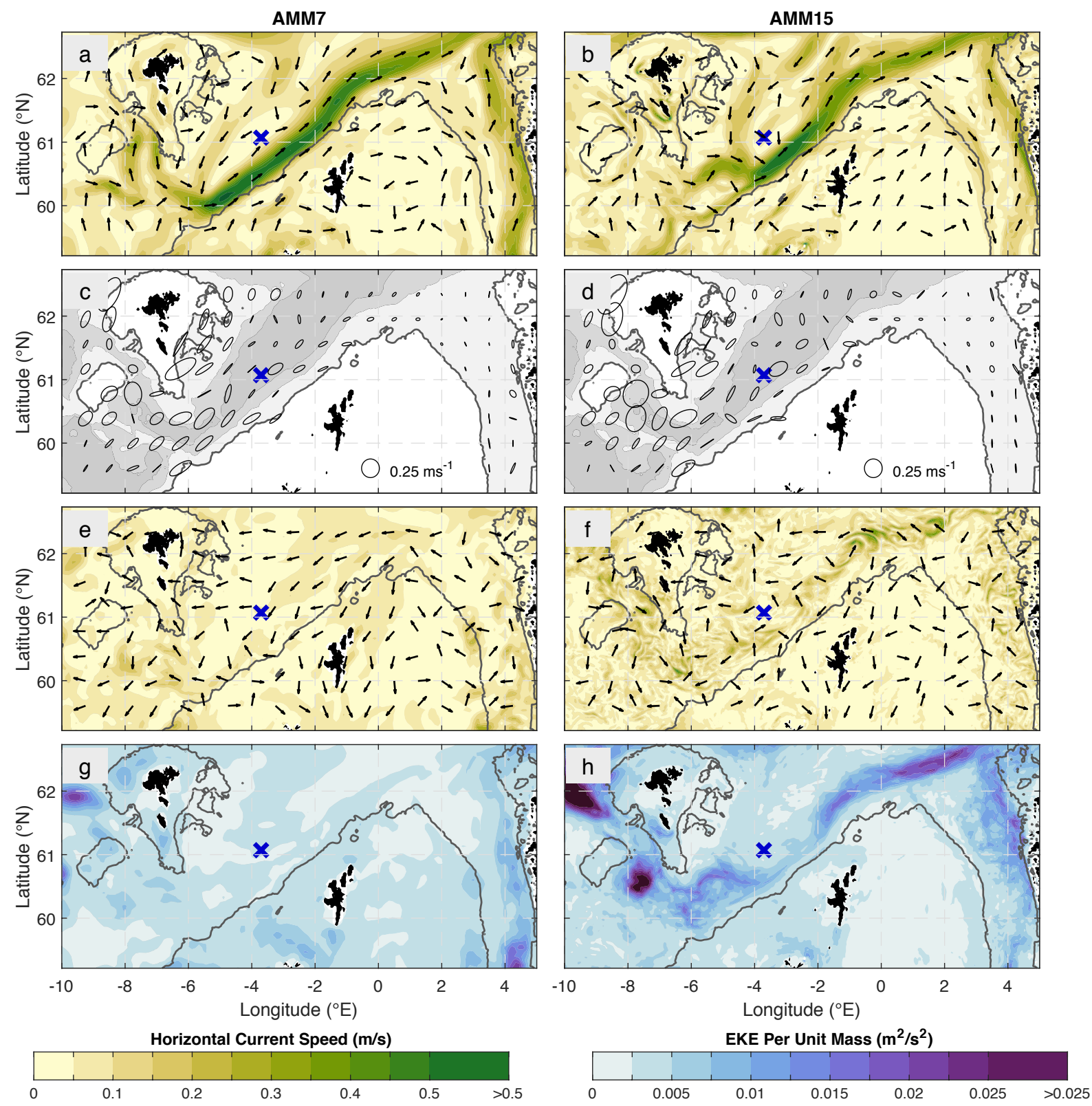

Fig. 2. Surface current decomposition for AMM7 and AMM15. (a, b) Thirty-day mean surface current velocity, with current magnitude shown as coloured contours and direction shown by arrows. (c, d) $M_{2}$ tidal ellipses, masked on the shelf $(<200 \mathrm{~m}$ ). (e, f) Residual surface current velocities at the end of the release period on 10 February 2017. (g, h) Thirty-day surface mean eddy kinetic energy (EKE) per unit mass. The shelf edge (200 $\mathrm{m}$ isobath) is shown as a dark gray contour and release location is shown as a blue cross. Bathymetry is identical to Fig. 1a.

\section{Modelling the oil spill}

Oil is released from the seabed (1122 m depth) on 1 February 2017 for nine days. The release location $\left(61.07^{\circ} \mathrm{N}, 3.705^{\circ} \mathrm{W}\right)$ was chosen because it is in an area with several active well heads (Fig. 1a). The simulation is run for 30 days, which accounts for the release period plus three weeks of further dispersion. A total of $100700 \mathrm{~m}^{3}$ of oil is released at a constant rate of $0.130 \mathrm{~m}^{3} / \mathrm{s}$, guided by the estimate of Gallego et al. (2018). The oil exits from an orifice with diameter $0.1 \mathrm{~m}$, similar 
to the DeepSpill field experiment (Johansen et al., 2003) and subsurface plume modelling by Yapa and Chen (2004), but small compared to Johansen (2000b; $0.29 \mathrm{~m}$ ) and Deepwater Horizon (0.5 $\mathrm{m})$. Smaller orifice diameters result in higher exit velocities and smaller droplet diameters. Clair oil type is used, with a density of $893.8 \mathrm{~kg} / \mathrm{m}^{3}$ and an initial temperature of $10^{\circ} \mathrm{C}$ (Clair oil default values). Methane gas is released alongside oil with a GOR of 200, similar to previous studies (Yapa and Chen, 2004). Gas hydrate formation is allowed and hydrates were present during the plume phase (with a density of $930 \mathrm{~kg} / \mathrm{m}^{3}$; Johansen, 2000a). Johansen (2003) suggest that hydrate formation is limited by under-saturation of gas in the plume and so the simulations presented here may have a shallower trapping depth than reality.

The plume model timestep is $5 \mathrm{~s}$ and the plume is terminated when vertical velocity reaches zero. Plume profiles are computed hourly to capture variability over the semidiurnal tidal cycle. The 3-D fates model timestep is 10 minutes. A total of 30000 liquid/solid particles, 30000 dissolved particles and 30000 gas particles are used to track the far-field fate of the pollutant within the model domain $\left(57-62.75^{\circ} \mathrm{N}, 12^{\circ} \mathrm{W}-6^{\circ} \mathrm{E}\right)$. This domain is restrictive at the northern boundary due to the extent of the AMM15 domain. Oil that travels outside of the model domain is defined as 'escaped' and is almost exclusively from the surface. Vertical resolution is $50 \mathrm{~m}$ and horizontal resolution is $1.5 \mathrm{~km}$ for both simulations, ensuring that spill dynamics are captured on the same spatial scale as the finest resolution hydrodynamic model. Oil that reaches the surface is tracked and can emulsify with the seawater or evaporate.

The hydrodynamic models are used as forcing only and are not coupled with OSCAR. Horizontal current velocities are interpolated (nearest-neighbour) onto the 3-D fates model grid. In the plume model, standard method 2520C (Millero and Poisson, 1981) is used to calculate density and buoyancy frequency squared $\left(N^{2}\right)$ from in-situ temperature and practical salinity. Practical salinity is a direct output of the hydrodynamic models; in-situ temperature is calculated from output potential temperature using the Gibbs Seawater oceanographic toolbox (McDougall and Barker, 2011). The operational outputs of AMM7 and AMM15 do not extend to the seabed, so values of temperature and salinity deeper than $1000 \mathrm{~m}$ are extrapolated using a nearest-neighbor method.

\section{Results}

\subsection{Surface transport}

Pollutant at the surface for the AMM7 release resides close to, and slightly west of, the release location for approximately two weeks (Fig. 3a, c). The surface emulsion is then transported by the slope current in a continuous band north-eastwards, parallel to the $600 \mathrm{~m}$ isobath (Fig. 3e, g). For the AMM15 release, initial surface transport is north-eastwards, and the emulsion has already begun to diverge into two distinct branches by the end of the release period (Fig. 3b). The emulsion continues to travel along the FSC in separate patches that become increasingly small and numerous (Fig. 3d, f, h). Some of the emulsion is transported by the slope current, but the majority resides further west. Differences in surface transport between simulations can be partly accounted for by differences in the mean surface circulation (Fig. 2a, b); for both hydrodynamic models, a surface current recirculates water anti-clockwise around the south of the release location. The location of this recirculation is different for AMM7 and AMM15. There are relatively high velocities $(>0.2$ $\mathrm{m} / \mathrm{s})$ close to the release location for AMM15, but a region of lower velocities $(<0.05 \mathrm{~m} / \mathrm{s})$ to the west for AMM7. This explains the initial retention of surface emulsion around the release location. The substantially higher surface EKE along the shelf slope for AMM15 (Fig. 2h) is a potential 
mechanism for diverting pollutant away from the primary slope current. No surface emulsion is transported onto the shelf $(<200 \mathrm{~m})$ for either model run, but the distribution would likely change with the inclusion of direct wind forcing towards the north-east, as is typical for the region during February (Gallego et al., 2018).
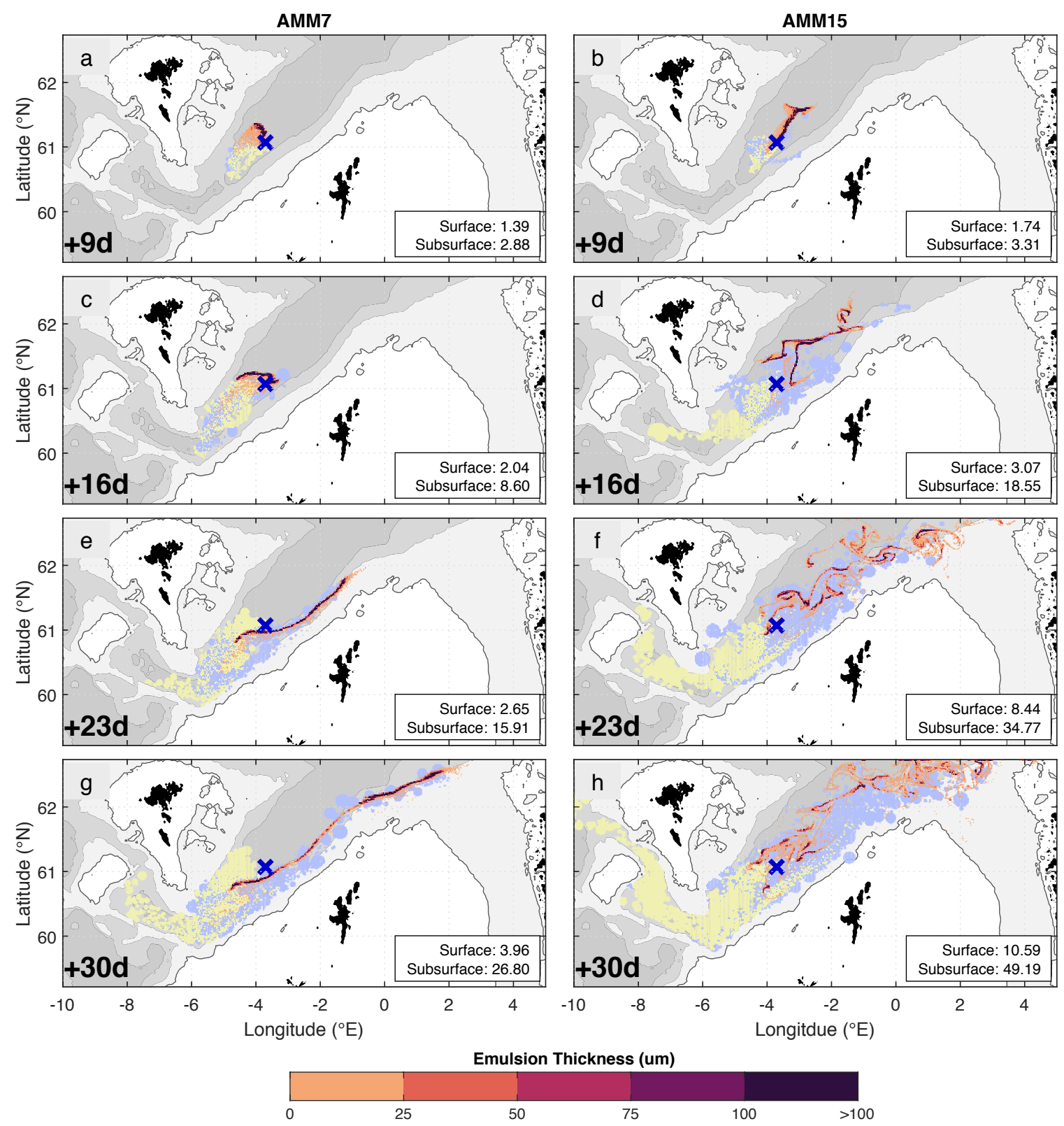

Fig. 3. Far-field transport of pollutant. $(a, b)$ Surface emulsion thickness nine days after the beginning of the release (colour scale). Light blue and yellow both show where depth-integrated subsurface pollutant exceeds $5 \mathrm{~kg} / \mathrm{km}^{2}$, but with maximum concentration shallower and deeper than $500 \mathrm{~m}$, respectively. The white box in the corner of each panel shows the total area of surface and subsurface pollutant $\left(10^{9} \mathrm{~m}^{2}\right)$. (c, d) As $(a, b)$, but 16 days after the beginning of the simulation. (e, f) As $(a, b)$, but 23 days after the beginning of the simulation. $(\mathrm{g}, \mathrm{h})$ As $(\mathrm{a}, \mathrm{b})$, but 30 days after the beginning of the simulation. The shelf edge $(200 \mathrm{~m}$ isobath) is shown as a dark gray contour and release location is shown as a blue cross. Bathymetry is identical to Fig. 1 a. 


\begin{tabular}{|l|c|c|}
\hline Component & AMM7 (\%) & AMM15 (\%) \\
\hline On surface & 74.69 & 68.78 \\
\hline Evaporated & 12.67 & 13.24 \\
\hline Submerged & 12.64 & 12.26 \\
\hline Biodegraded & 0.00 & 0.00 \\
\hline In sediment & 0.01 & 0.15 \\
\hline Outside model domain & 0.00 & 5.57 \\
\hline
\end{tabular}

Table 1. Mass balance for different model components at the end of the simulation period (30 days).

For both releases, approximately $87.5 \%$ of oil has surfaced after 30 days (Table 1), consisting of an oil-water emulsion (75\%) and more volatile components that have evaporated (12.5\%). For the AMM15 release, $5.6 \%$ of oil escapes the north-west boundary of the domain (compared to zero for AMM7), but this mass is assumed to be part of the oil-water emulsion because it escapes during the final five days and is almost exclusively from the surface.

After nine days, the surface area of the AMM15 release is greater than the AMM7 release by a factor of 1.25. The proportion of the total mass of oil residing on the sea surface at this time is $72 \%$ for both releases. The emulsion from the AMM15 release has not had sufficient time to break up into multiple patches, and the full effect of additional mesoscale variability cannot yet be seen quantitatively. After 30 days, the surface area of the AMM15 release is greater by a factor of 2.7. The total mass of oil on the surface at the end of the simulation is similar, so cannot account for the increase. However, mean water content in the emulsion is higher (43.2\% compared with $33.2 \%$ for AMM7), and the mean emulsion thickness is lower $(14.0 \mu \mathrm{m}$ compared with $31.1 \mu \mathrm{m})$. Thus, there is a higher volume of emulsion spread more thinly, likely due increased EKE available for dispersion and emulsification.

\subsection{Subsurface transport}

For both releases, approximately $12.5 \%$ of oil remains below the surface after 30 days. Most of this $(90 \%)$ is dissolved into the water column. The remaining mass consists of small $(<100 \mu \mathrm{m})$ liquid droplets, which have an almost neutral buoyancy. In reality, these droplets will either remain within the water column indefinitely, slowly rise to the surface, mix with sediment, dissolve, or biodegrade (Beyer et al., 2016).

Trapping depth, where vertical velocity of the plume reaches zero, is different for each simulation (Fig. 4). For the AMM7 release, trapping depth is 570-775 m, with an average of 622 $\mathrm{m}$. For the AMM15 release, trapping depth is $478-718 \mathrm{~m}$, with an average of $574 \mathrm{~m}$. To separate the influence of stratification and currents, we repeated the simulations with the same AMM7 and AMM15 stratifications, but with current velocity set to zero for both cases (not shown). This leads to a trapping depth of $595 \mathrm{~m}$ and $497 \mathrm{~m}$, respectively. The plume traps at a greater depth for the AMM7 release as a result of increased $N^{2}$ at 450-1000 m, and thus increased energy required to advect entrained water compared to the AMM15 release (Fig. $4 \mathrm{~d}, \mathrm{f}$ ). This difference in $N^{2}$ is apparent across the FSC (Fig. 1d, e). Current flow also acts to deepen the trapping depth, and this varies semidiurnally (Fig. 4c, e). The horizontal distribution of trapping shows an asymmetric, approximately rectilinear tide parallel to the shelf slope and with a bias to the south-west (Fig. 4a, b). The maximum concentration of trapped oil at the end of the release period (not shown) is typically $75 \mathrm{~m}$ above the top of the plume, at $550 \mathrm{~m}$ (AMM7) and $500 \mathrm{~m}$ (AMM15). 
Subsurface transport can be divided into two primary pathways. Deep oil (maximum concentration deeper than $500 \mathrm{~m}$ ) is transported westwards through the Faroe Bank Channel and restricted by the relatively shallow Wyville Thomson Ridge. This transport is more rapid for the AMM15 release, with oil reaching the western boundary of the model domain. Shallow oil (maximum concentration shallower than $500 \mathrm{~m}$ ) is transported north-eastwards through the FSC along the continental slope, following a similar trajectory to the surface emulsion. Pollutant from the AMM7 release resides close to the shelf edge, but for AMM15 it is spread more broadly across the FSC. Oil escapes from the surface at the northern boundary for the AMM15 release.
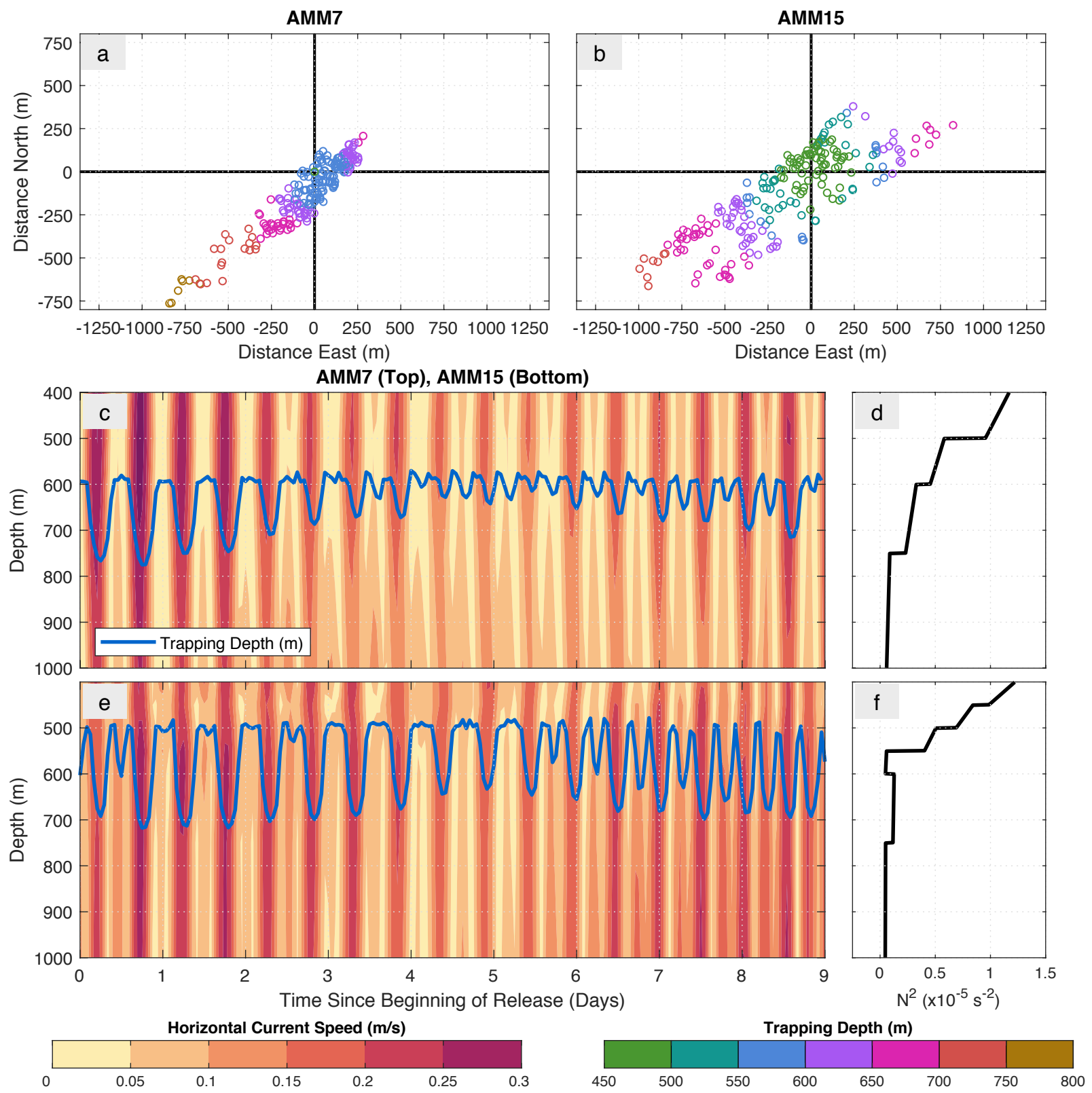

Fig. 4. Plume dynamics. (a, b) Trapping location of the subsurface plume for AMM7 (left) and AMM15 (right), relative to the release location. (c) Contoured current speed from AMM7 at the release location, where the blue line indicates trapping depth. (d) Buoyancy frequency squared used by OSCAR from AMM7. (e, f) As (c, d), but for AMM15. 
After nine days, the area of subsurface oil is $15 \%$ higher for the AMM15 release than for the AMM7 release (Fig. 3a, b). This is partly a consequence of an increased spread of plume trapping locations (Fig. 4a, b). After 30 days, there is almost twice the area of subsurface oil. Higher EKE for AMM15 through the water column may contribute to increased deep horizontal dispersion (Fig. 5). Enhanced mesoscale variability down to $800 \mathrm{~m}$ has also been previously observed within the FSC (Dooley and Meincke, 1981; Sherwin et al., 1999). A second contributing factor for increased dispersion for the AMM15 release could be higher mean current velocities at depth, particularly south of the Faroe Islands at $600 \mathrm{~m}$ and $750 \mathrm{~m}$ (Fig. 6), which will result in oil at these depths transported more rapidly away from the release location.
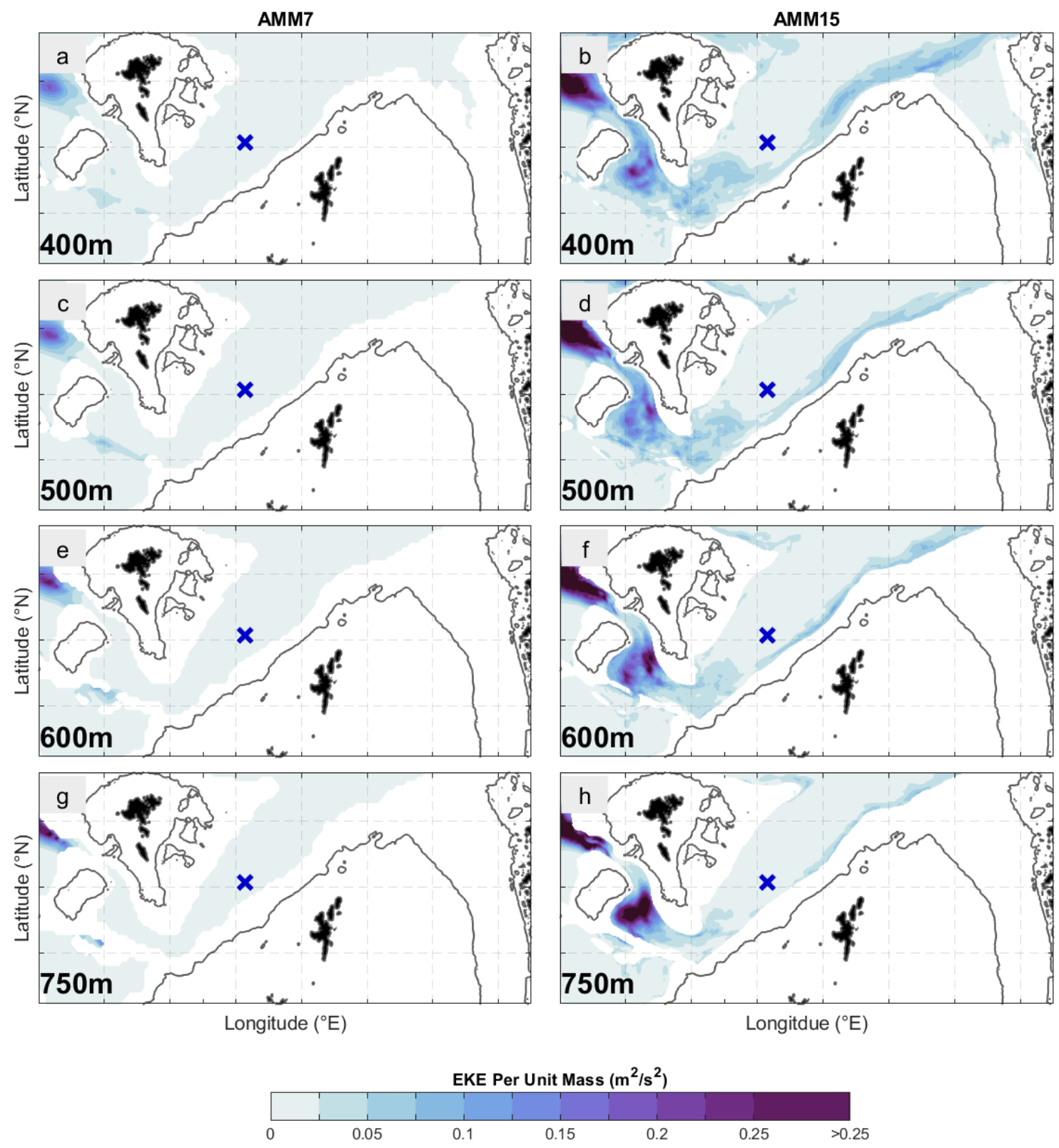

Fig. 5. Monthly mean EKE per unit mass at different depths for AMM7 and AMM15. (a, b) 400 m. (c, d) $500 \mathrm{~m}$. (e, f) $600 \mathrm{~m}$. (g, h) $750 \mathrm{~m}$. The shelf edge (200 m isobath) is shown as a dark gray contour and release location is shown as a blue cross. Bathymetry is identical to Fig. 1a. 

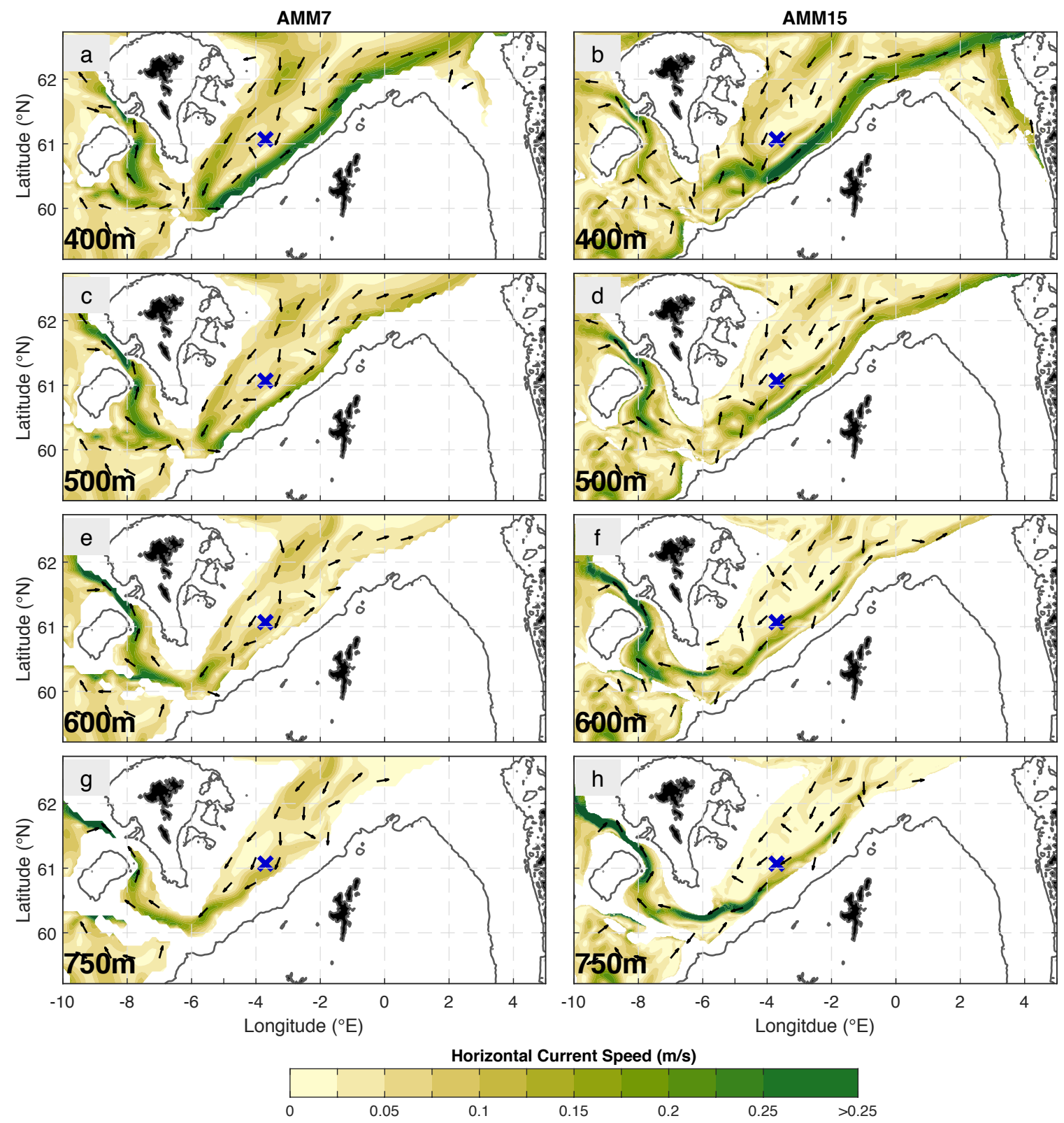

Fig. 6. Monthly mean current velocities at different depths for AMM7 and AMM15. (a, b) $400 \mathrm{~m}$. (c, d) $500 \mathrm{~m}$. (e, f) $600 \mathrm{~m}$. (g, h) $750 \mathrm{~m}$. Current magnitude is shown as coloured contours and direction is shown by arrows. The shelf edge ( $200 \mathrm{~m}$ isobath) is shown as a dark gray contour and release location is shown as a blue cross. Bathymetry is identical to Fig. 1a.

\section{Discussion}

Oil transport from a deep water release in the central FSC will divide into two main pathways. Oil that has reached the surface, in addition to oil trapped in the upper portion of the water column, will predominantly travel north-eastwards along the continental slope towards the Norwegian Sea. Deeper oil will be transported westwards, advected by deep currents and guided by bathymetry through the Faroe Bank Channel and eventually out into the open North Atlantic. No oil overflows the Wyville Thomson Ridge into the Rockall Trough in these simulations. Using a finer resolution hydrodynamic model that explicitly resolves mesoscale processes increases the amount of EKE 
available for the horizontal dispersion of oil and its emulsification at the sea surface. This leads to increased spatial coverage, as well as a thinner emulsion with a higher water content.

When forcing OSCAR with fine-resolution, mesoscale eddy-resolving hydrodynamic models, consideration should be made to the internal horizontal turbulent diffusivity $\left(K_{x}\right)$, which is a function of the internal timestep (Pan et al., 2020). This parameter has been tuned for optimal results with coarser resolution models, in part to parameterise unresolved 'eddy' diffusivity. This may lead to an overestimation of horizontal dispersion when forcing with eddy-resolving models. Improvements could be made by implementing horizontal and vertical diffusivities direct from the forcing model. However, at present, these parameters are not typically output operationally.

The large-scale transport pathways presented here broadly agree with a previous modelling study by Main et al., (2017), who found that oil transported at $400 \mathrm{~m}$ and shallower consistently reached the Norwegian Sea, whereas deeper transport was predominantly westwards. Our study builds upon this research by considering the vertical distribution of oil from a plume model, the trajectory of particles that are not neutrally buoyant, and smaller spatial scales that are more useful for emergency response. Emulsification and evaporation have also been considered, and have an influence on the total mass of oil on the sea surface.

Our study also predicts the range of depths that oil will become trapped at within the FSC and the proportion of oil trapped within the water column. A previous plume modelling study (Johansen, 2000b) suggested that oil will be trapped at 650-800 m depth from a $1000 \mathrm{~m}$ release in the FSC, depending on stratification, ocean currents and release rate. This is deeper than the average trapping depth for the AMM15 release by 150-300 m, but Johansen (2000b) used a lower release rate range $\left(0.018-0.035 \mathrm{~m}^{3} / \mathrm{s}\right.$ compared to $\left.0.130 \mathrm{~m}^{3} / \mathrm{s}\right)$, which will act to deepen the trapped plume (Johansen, 2000b; Yapa and Chen, 2004). Our results suggest that trapping depth does not substantially influence the overall surfacing time or the proportion of oil trapped below the surface. Yapa and Chen (2004) made similar conclusions by modelling plumes for typical stratification and current profiles from the North Sea and Gulf of Mexico. However, our results also suggest that trapping depth indirectly influences oil trajectory in the far-field through differential advection by surface and subsurface currents.

Neither oil biodegradation or the direct influence of wind is considered here. The rate of oil biodegradation depends on temperature, local bacterial colonies and the chemical composition of the pollutant (Beyer et al., 2016). The inclusion of biodegradation in the model will limit the extent of subsurface transport and reduce the risk of contamination far from the release location. However Main et al. (2017) showed that oil could still reach west of Iceland and within the Arctic Circle before fully biodegrading.

Direct wind forcing is not included here because the intention is to show the exclusive influence of ocean currents. However, both AMM7 and AMM15 are forced by wind fields (Tonani et al., 2019), so although there is no direct forcing there is an indirect influence of wind in the upper water column. Wind will have no influence on transport below the Ekman layer, which is approximately $150 \mathrm{~m}$ deep at $60^{\circ} \mathrm{N}$ assuming a typical wind speed of $10 \mathrm{~m} / \mathrm{s}$ in February. The direct (Stokes) component of surface oil trajectory is typically calculated as $3.6 \%$ of surface wind velocity (Reed et al., 1995), and the presence of a wind field will also increase evaporation, emulsification and natural dispersion. Further simulations will be required to assess the relative importance of hydrodynamic and wind forcing in the region. 


\section{Summary}

This study provides an insight into how a hydrodynamic model with resolution fine enough to resolve mesoscale processes influences the predicted dispersion of oil from a deep seabed release. The modelling systems used here are currently in use by spill responders; this study therefore serves to directly inform industry of what is missed by coarser resolution hydrodynamic models, and how that may impact real-world predictions. Additional hazards that have been uncovered include the potential for subsurface pollutant to travel rapidly from the release location, and increased spatial coverage of the surface emulsion. Both of these will increase the difficulty of a clean-up operation. Results from this study demonstrate how the choice of hydrodynamic model resolution can lead to substantially different outcomes, and can be applied to a wide range of particle tracking and tracer release applications, for example marine plastic pollution or dispersion of benthic faunal larvae.

\section{Acknowledgments}

RMG was funded by the UK Natural Environment Research Council (NERC) industrial CASE studentship grant NE/M010023/1, awarded to the University of East Anglia and Cefas, and an associate member of the NERC EnvEast Doctoral Training Program. We particularly thank SINTEF for support with OSCAR. Well head data (latitude, longitude, depth and status) are available from https://www.ogauthority.co.uk/data-centre/data-downloads-and-publications/welldata/. This study has been conducted using EU Copernicus Marine Service Information. AMM7 and AMM15 output are available from http://marine.copernicus.eu/services-portfolio/access-toproducts/. Hourly evolution of both oil spill simulations can be viewed as animations via the supplementary material (Videos S1 and S2).

\section{Declaration of interest}

The authors declare that they have no known competing financial interests or personal relationships that could have appeared to influence the work reported in this paper.

\section{References}

Aamo, O. M., Reed, M., Downing, K., 1997. Oil Spill Contingency and Response (OSCAR): Sensitivity Studies. International Oil Spill Conference (IOSC) 1997(1), 429-438. https://doi.org/10.7901/2169-3358-1997-1-429.

Abascal, A. J., Castanedo, S., Medina, R., Liste, M., 2010. Analysis of the reliability of a statistical oil spill response model. Marine Pollution Bulletin 60(11), 2099-2110. https://doi.org/10.1016/j.marpolbul.2010.07.008.

Berx, B., Hansen, B., Østerhus, S., Larsen, K. M., Sherwin, T. J., Jochumsen, K., 2013. Combining in situ measurements and altimetry to estimate volume, heat and salt transport variability through the Faroe-Shetland Channel. Ocean Science 9(4), 639-654. https://doi.org/10.5194/os-9-639-2013.

Beyer, J., Trannum, H. C., Bakke, T., Hodson, P. V, Collier, T. K., 2016. Environmental effects of the Deepwater Horizon oil spill: A review. Marine Pollution Bulletin 110(1), 28-51. https://doi.org/10.1016/j.marpolbul.2016.06.027. 
Burgherr, P., 2007. In-depth analysis of accidental oil spills from tankers in the context of global spill trends from all sources. Journal of Hazardous Materials 140(1-2), 245-256. https://doi.org/10.1016/j.jhazmat.2006.07.030.

Camilli, R., Reddy, C. M., Yoerger, D. R., van Mooy, B. A. S., Jakuba, M. V, Kinsey, J. C., ... Maloney, J. V., 2010. Tracking Hydrocarbon Plume Transport and Biodegradation at Deepwater Horizon. Science 330(6001), 201-204. https://doi.org/10.1126/science.1195223.

Codiga, D. L., 2011. Unified tidal analysis and prediction using the UTide Matlab functions. Graduate School of Oceanography, University of Rhode Island Narragansett, RI.

Crone, T. J., Tolstoy, M., 2010. Magnitude of the 2010 Gulf of Mexico Oil Leak. Science 330(6004), 634. https://doi.org/10.1126/science.1195840.

Darelius, E., Fer, I., Quadfasel, D., 2011. Faroe Bank Channel Overflow: Mesoscale Variability. Journal of Physical Oceanography 41(11), 2137-2154. https://doi.org/10.1175/jpo-d-11035.1 .

Dooley, H. D., Meincke, J., 1981. Circulation and Water Masses in the Faroese Channels during Overflow '73. Deutsche Hydrographische Zeitschrift 34(2), 41-55. https://doi.org/10.1007/BF02226585.

EU Copernicus Marine Services Information, 2018a. European North West Shelf - Ocean physics analysis: NORTHWESTSHELF_ANALYSIS_FORECAST_PHY_004_001_b.

EU Copernicus Marine Services Information, 2018b. European North West Shelf - Ocean physics analysis: NORTHWESTSHELF_ANALYSIS_FORECAST_PHY_004_13.

Gallego, A., Murray, R., Berx, B., Turrell, W. R., Beegle-Krause, C. J., Inall, M. E., ... Mulanaphy, N., 2018. Current status of deepwater oil spill modelling in the Faroe-Shetland Channel, Northeast Atlantic, and future challenges. Marine Pollution Bulletin 127, 484-504. https://doi.org/10.1016/j.marpolbul.2017.12.002.

Graham, J. A., O’Dea, E., Holt, J. T., Polton, J., Hewitt, H. T., Furner, R., ... Adame, C. G. M., 2018. AMM15: a new high-resolution NEMO configuration for operational simulation of the European north-west shelf. Geoscientific Model Development 11(2), 681-696. https://doi.org/10.5194/gmd-11-681-2018.

Guihou, K., Polton, J., Harle, J., Wakelin, S., O’Dea, E., Holt, J. T., 2017. Kilometric Scale Modeling of the North West European Shelf Seas: Exploring the Spatial and Temporal Variability of Internal Tides. Journal of Geophysical Research: Oceans 123(1), 688-707. https://doi.org/10.1002/2017jc012960.

Hall, R. A., Berx, B., Damerell, G. M., 2019. Internal tide energy flux over a ridge measured by a co-located ocean glider and moored acoustic Doppler current profiler. Ocean Science 15, 1439-1453. https://doi.org/10.5194/os-15-1439-2019.

Hall, R. A., Huthnance, J. M., Williams, R. G., 2011. Internal tides , nonlinear internal wave trains, 
and mixing in the Faroe-Shetland Channel. Journal of Geophysical Research 116(C3). https://doi.org/10.1029/2010jc006213.

Hosegood, P., van Haren, H., 2004. Near-bed solibores over the continental slope in the FaeroeShetland Channel. Deep Sea Research Part II: Topical Studies in Oceanography 51(25-26), 2943-2971. https://doi.org/10.1016/j.dsr2.2004.09.016.

Johansen, Ø., 2000a. DeepBlow - a Lagrangian Plume Model for Deep Water Blowouts. Spill Science \& Technology Bulletin 6(2), 103-111. https://doi.org/10.1016/s13532561(00)00042-6.

Johansen, Ø., 2000b. Simulations of Near Field Spreading from Potential Blowouts in Deep Waters South of Faroe Islands. Retrieved from http://projects.foib.fo/eia/Faroe_eia/Studies/Subsurface_Blowout_Final.pdf

Johansen, Ø., 2003. Development and verification of deep-water blowout models. Marine Pollution Bulletin 47(9-12), 360-368. https://doi.org/10.1016/S0025-326X(03)00202-9.

Johansen, Ø., Brandvik, P. J., Farooq, U., 2013. Droplet breakup in subsea oil releases - Part 2: Predictions of droplet size distributions with and without injection of chemical dispersants. Marine Pollution Bulletin 73(1), 327-335. https://doi.org/10.1016/j.marpolbul.2013.04.012.

Johansen, Ø., Rye, H., Cooper, C., 2003. DeepSpill - Field Study of a Simulated Oil and Gas Blowout in Deep Water. Spill Science \& Technology Bulletin 8(5-6), 433-443. https://doi.org/10.1016/s1353-2561(02)00123-8.

Joye, S. B., Bracco, A., Özgökmen, T. M., Chanton, J. P., Grosell, M., MacDonald, I. R., ... Passow, U., 2016. The Gulf of Mexico ecosystem, six years after the Macondo oil well blowout. Deep Sea Research Part II: Topical Studies in Oceanography 129, 4-19. https://doi.org/10.1016/j.dsr2.2016.04.018.

King, R., While, J., Martin, M. J., Lea, D., Lemiuex-Dudon, B., Waters, J., O’Dea, E., 2018. Improving the initialisation of the Met Office operational shelf-seas model. Ocean Modelling 130, 1-14. https://doi.org/10.1016/j.ocemod.2018.07.004.

Lee, Y. G., Garza-Gomez, X., Lee, R. M., 2018. Ultimate Costs of the Disaster: Seven Years After the Deepwater Horizon Oil Spill. Journal of Corporate Accounting \& Finance 29(1), 69-79. https://doi.org/10.1002/jcaf.22306.

Madec, G., 2016. NEMO ocean engine. Note du Pole de modélisation (27th ed.). Institut PierreSimon Laplace.

Main, C. E., Yool, A., Holliday, N. P., Popova, E. E., Jones, D. O. B., Ruhl, H. A., 2017. Simulating pathways of subsurface oil in the Faroe-Shetland Channel using an ocean general circulation model. Marine Pollution Bulletin 114(1), 315-326. https://doi.org/10.1016/j.marpolbul.2016.09.041.

McDougall, T. J., Barker, P. M., 2011. Getting started with TEOS-10 and the Gibbs Seawater 
(GSW) oceanographic toolbox. In SCOR/IAPSO WG (Vol. 127).

McNutt, M. K., Camilli, R., Crone, T. J., Guthrie, G. D., Hsieh, P. A., Ryerson, T. B., ... Shaffer, F., 2012. Review of flow rate estimates of the Deepwater Horizon oil spill. Proceedings of the National Academy of Sciences 109(50), 20260-20267. https://doi.org/10.1073/pnas.1112139108.

Millero, F. J., Poisson, A., 1981. International one-atmosphere equation of state of seawater. Deep Sea Research Part A. Oceanographic Research Papers 28(6), 625-629. https://doi.org/10.1016/0198-0149(81)90122-9.

O’Dea, E., Arnold, A. K., Edwards, K. P., Furner, R., Hyder, P., Martin, M. J., ... Liu, H., 2012. An operational ocean forecast system incorporating NEMO and SST data assimilation for the tidally driven European North-West shelf. Journal of Operational Oceanography 5(1), 3-17. https://doi.org/10.1080/1755876x.2012.11020128.

O’Dea, E., Furner, R., Wakelin, S., Siddorn, J., While, J., Sykes, P., ... Hewitt, H., 2017. The CO5 configuration of the $7 \mathrm{~km}$ Atlantic Margin Model: large-scale biases and sensitivity to forcing, physics options and vertical resolution. Geoscientific Model Development 10, 2947-2969. https://doi.org/10.5194/gmd-10-2947-2017.

Oey, L. Y., 1998. Eddy energetics in the Faroe-Shetland Channel: A model resolution study. Continental Shelf Research 17(15), 1929-1944. https://doi.org/10.1016/s02784343(97)00053-8.

Pan, Q., Yu, H., Daling, P. S., Zang, Y., Reed, M., Wang, Z., ... Zou, Y., 2020. Fate and behavior of Sanchi oil spill transported by the Kuroshio during January-February 2018. Marine Pollution Bulletin 152, 110917. https://doi.org/10.1016/j.marpolbul.2020.110917.

Reed, M., Daling, P. S., Brakstad, O. G., Singsaas, I., Faksness, L. G., Hetland, B., Ekrol, N., 2000. OSCAR2000 : a multi-component 3-dimensional oil spill contingency and response model. Proceedings of the 23. Arctic and Marine Oilspill Program (AMOP) Technical Seminar. Retrieved from https://inis.iaea.org/search/search.aspx?orig_q=RN:31063064.

Reed, M., Rines, H., Drive, D. K., Rye, H., 1995. A Three-Dimensional Oil and Chemical Spill Model for Environmental Impact Assessment. International Oil Spill Conference (IOSC) 1995(1), 61-66. https://doi.org/10.7901/2169-3358-1995-1-61.

Sherwin, T. J., 1991. Evidence of a deep internal tide in the Faeroe-Shetland Channel. In Tidal Hydrodynamics (pp. 469-488). Retrieved from http://www.nmbl.org/cgi-bin/koha/opacdetail.pl?biblionumber $=58361 \&$ shelfbrowse_itemnumber $=58784$.

Sherwin, T. J., Griffiths, C. R., Inall, M. E., Turrell, W. R., 2008. Quantifying the overflow across the Wyville Thomson Ridge into the Rockall Trough. Deep Sea Research Part I: Oceanographic Research Papers 55(4), 396-404. https://doi.org/10.1016/j.dsr.2007.12.006.

Sherwin, T. J., Turrell, W. R., Jeans, D. R. G., Dye, S., 1999. Eddies and a mesoscale deflection of the slope current in the Faroe-Shetland Channel. Deep Sea Research Part I: Oceanographic 
Research Papers 46(3), 415-438. https://doi.org/10.1016/s0967-0637(98)00077-6.

Sherwin, T. J., Williams, M. O., Turrell, W. R., Hughes, S. L., Miller, P. I., 2006. A description and analysis of mesoscale variability in the Färoe-Shetland Channel. Journal of Geophysical Research 111(C3). https://doi.org/10.1029/2005jc002867.

Smallwood, J. R., Kirk, W. J., 2005. Paleocene exploration in the Faroe-Shetland Channel: disappointments and discoveries. Geological Society, London, Petroleum Geology Conference Series 6(1), 977-991. https://doi.org/10.1144/0060977.

Smith, W. H. F., Sandwell, D. T., 1997. Global Sea Floor Topography from Satellite Altimetry and Ship Depth Soundings. Science 277(5334), 1956-1962. https://doi.org/10.1126/science.277.5334.1956.

Tonani, M., Sykes, P., King, R. R., McConnel, N., Pequignet, A., O’Dea, E., ... Siddorn, J. R., 2019. The impact of a new high-resolution ocean model on the Met Office North-West European Shelf forecasting system. Ocean Science, 15, 1133-1158. https://doi.org /10.5194/os-15-1133-2019.

Turrell, W. R., Slesser, G., Adams, R. D., Payne, R., GIllibrand, P. A., 1999. Decadal variability in the composition of Faroe Shetland Channel bottom water. Deep Sea Research Part I: Oceanographic Research Papers 46(1), 1-25. https://doi.org/10.1016/s0967-0637(98)000673.

Yapa, P. D., Chen, F., 2004. Behavior of oil and gas from deepwater blowouts. Journal of Hydraulic Engineering 130(6), 540-553. https://doi.org/10.1061/(asce)07339429(2004)130:6(540). 